\title{
Cash Advance Accounting: Accounting Regulations and Practices
}

\author{
Aristița Rotilă, Lecturer, University “Vasile Alecsandri” of Bacău, România
}

\begin{abstract}
It is known the fact that often the entities offer to staff or third parties certain amounts of money, in order to make payments for the entities, such sums being registered differently in the accounting as cash advances. In the case in which the advances are offered in a foreign currency, there is the problem of the exchange rate used when justifying the advance, for the conversion in lei of payments that were carried out. In this article we wanted to signal the effect that the exchange rate, used in the assessment for reflecting in the accounting operations concerning cash advance reimbursements in a foreign currency, has on the information presented in the financial statement. Therewith, we signal some aspects from the content of the accounting regulations, with reference at defining the cash advances, meaning, and the presentation in the balance sheet of cash advances, which, in our opinion, impose clarifications.
\end{abstract}

\section{Key-words}

cash advances, exchange rate, differences of exchange rate, operating income, gross result

\section{Cod JEL: M41}

Analyzing the accounting regulations in compliance with the European Directives applicable to economic operators, more precisely the statements concerning the cash advances, as well as the opinions presented in the specialized literature in relation with the reflection in the accounting of cash advances in a foreign currency, we notice that there are some aspects that should be clarified. Therefore, in our opinion, at least the following aspects are to be taken into consideration: the exchange rate used for the conversion in lei of payments done in the foreign currency that were paid from cash advances with the occasion of the assessment for accounting the justification (reimbursement) of these payments and also, the influence of the exchange rate on the information presented in the financial statements; the presentation in the financial statements of the amounts, representing cash advances offered according to law and which were not settled until the date of the balance; the content of the accounting structure, called cash advance, or, in other terms, the determination of the cash advances and the account reserved for their registration.

\section{About the Justification of Cash Advances in the Foreign Currency}

The payments that were done from cash advances may aim different categories of operating expenses, meaning "expenses representing the value of the materials that are not stored, energy and water consumption, maintenance and repairs, insurance bonuses, studies and research developed by third parties, commissions and payments, entertainment, commercial and advertising, goods' transportation, traveling, posts and telecommunications, other services developed by third parties" 1 .

\footnotetext{
${ }^{1}$ The Order of the Public Finances Minister no. 3055/2009, Chapter VII Operation of Accounts, Account 542 "Cash advance"
} 
In the case in which cash advances are granted in a foreign currency the problem that may appear is of the exchange rate used at the justification of the advance, for the conversion in lei of payments that were carried out. The accounting regulations in compliance with European directives applicable to economic operators, from point 176, paragraph (2), state that "in case of payments in the foreign currency carried out from cash advances, the expenses may be recognized in accounting at the exchange rate from the date the operations were developed or at the rate from the date of the advance reimbursement". Therefore the entities have the possibility to choose the conversion in lei for the expenses done in a foreign currency at the exchange rate from the date written in the documents, that is the payment date, or at the rate from the date of the justification of the advance, ergo the date of submission of expense reimbursement. What will be the effect? Will there be different expenses and results?

At a first reading of the text of the Accounting regulations we will be tempted to believe the fact that the option for one of the two values of the exchange rate will generate an operation expense, higher or lower, and, therefore, will influence the result of the financial year. At a more detailed analysis of these aspects we may observe that no matter the option, the gross result of the financial year will be the same, but there will be a transfer of results from the operating activity to result from the financial activity or the other way around, according to case. Naturally the option for a rate or another will lead to recognizing in the accounting some higher or lower operating expenses, according to the exchange rate at which the assessment is done and which is higher or lower. However using an exchange rate which is higher or lower will lead to recognizing some exchange gains or losses related with the foreign currency that the entity holds as cash advances. Practically, an increased operating expense, as result of using a higher exchange rate, will be compensated by the appearance of an exchange gain related with the cash advances, and a diminished operating expense, as result of using a lower exchange rate, will be compensated by the appearance of an exchange loss related to cash advances. We will demonstrate the information from above through two examples, the first for the case in which the exchange rate is increasing in time (from the moment when the advance was granted and until the payments are done, that is, up to the moment of the justification) and the second one, for the case in which the exchange rate is decreasing in time.

Case 1: The advance given to the salaried for his/her traveling abroad was the amount of 1.000 euro, and the total amount of the expenses in a foreign currency, according to the reimbursement of expenses, was of 1.000 euro. The exchange rate evolved in the following way: at the date the advance was granted the rate was of 4, 30 lei/euro; at the date written in the expense documents 4, 32 lei/euro; at the date of the reimbursement of the advance 4, 35 lei/euro. Recognizing in accounting the expenses done with the occasion of the travel will be developed using on one hand the exchange rate written in the documents (Case 1.A) and, on the other hand, the exchange rate from the reimbursement of the advance (Case 1.B). The activity of recording in accounting the operations is presented like in Figure no. 1.

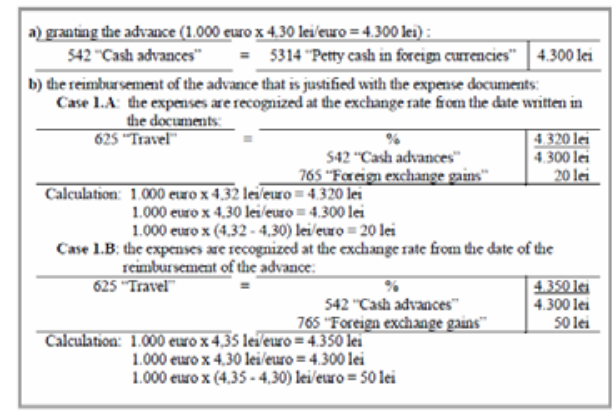

Figure no. 1. Reflecting in Accounting the Operations Concerning Granting and Justifying the Cash Advance - Case 1 
It is noticed that, no matter the exchange rate used for recognizing the expenses, the gross result will be influenced by the same value of 4.300 lei, meaning the amount of the payments in a foreign currency from the date of the granting of the advance. This value represents the difference between travel expenses and the exchange gain, meaning 4.320 lei - 20 lei (Case 1.A), 4.350 lei - 50 lei (Case 1.B). Therefore, when we use for the recognition of travel expenses a higher exchange rate, which automatically will generate a higher operating expense, simultaneously, with the increase of the expenses, appears an increase of the financial incomes from owing foreign currency. This increase of operating expenses will be compensated, in the profit and loss account, by the increase of the financial exchange gains, so that the gross result of the financial year will not be influenced by the used exchange rate (higher or lower). However, the travel expenses and the exchange gains are presented in the financial statement, that is, in the Profit and Loss Account, in different areas, the travel expenses relate to the operating activity and the exchange gains belong to the financial activity. Therefore, it takes place a diminish of the operating profit together with the increase of the profit from the financial activity. The effects on the Profit and Loss Account are represented by us in Figure no. 5 .

Case 2: The advance given to the salaried for traveling abroad was in amount of 1.000 euro, and the total amount of the expenses in a foreign currency, according to the reimbursement of expenses, was of 1.000 euro. The exchange rate evolved in the following way: at the date of the granting of the advance 4, 35 lei/euro; at the date of the documents 4, 32 lei/euro; at the date of the reimbursement of the advance 4, 30 lei/euro. The recognition in accounting of travel expenses will be done, on one hand by using the exchange rate from the date written in the documents (Case 2.A) and on the other hand, by using the exchange rate from the date of the reimbursement of the advance (Case 2.B). Recording in accounting the operations that are represented in Figure no.2.

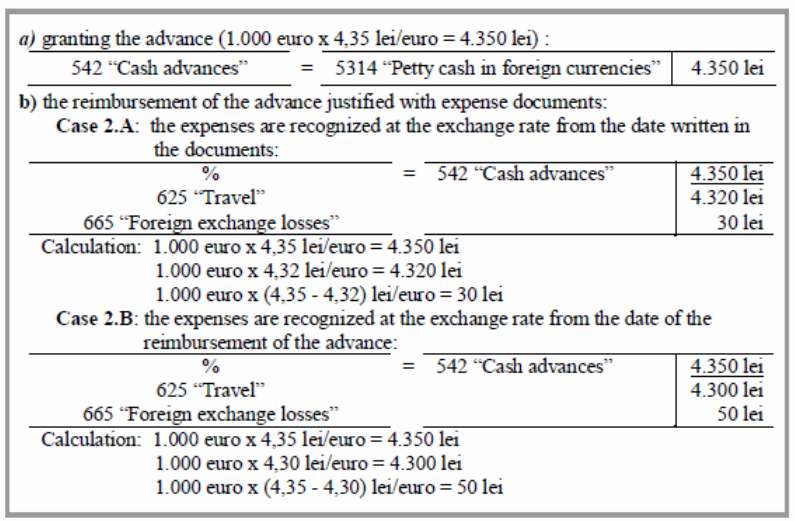

\section{Figure no. 2. Reflection in Accounting of Operations Concerning Granting and} Justifying the Cash Advance - Case 2

It is observed that, no matter the used exchange rate for the recognition of expenses, the gross result of the financial year will be influenced by the same amount 4.350 lei, meaning 4.320 lei (operating expenses) + 30 lei (exchange losses), in the Case 2.A, or 4.300 lei (operating expenses) +50 lei (exchange losses), Case 2.B.

In order to observe more clearly the effect of the exchange rate taken into consideration for the assessment and for the recognition of the expenses, in the examples from above, the exchange rate used for the crediting of the account 542 "Cash advance" is the one from the date when the advance was granted, the rate of the foreign currency. If we treat account 542 "Cash advances" in the same way as we treat all the accounts through which are shown 
cash liquidities in a foreign currency, each time we credit the account, the assessment of the currency will be done at the exchange rate from the date of that particular operation (rate of the day) and not at the one when the advance was granted, the rate of the foreign currency. This makes that, at the moment when the advance is being liquidated (be it totally justified on the basis of the documents, be it partially justified on the basis of the documents and the difference being returned at the pay desk) the account must present a balance in lei (due/credit balance), although its balance in a foreign currency is void. This credit/due balance, representing the advantageous/unadvantageous differences of exchange rate that resulted from the existence of advances paid in a foreign currency, will be liquidated, therefore debiting/crediting the account 542 "Cash advances", according to case, in correspondence with one of the accounts 765 "Foreign exchange gains" or account 665"Foreign exchange losses".

Continuing the example from above, in the conditions in which the used rate when crediting the account 542 "Cash Advances" is the same used for the assessment of the expenses, meaning the one from the date of that certain operation (rate of the day), the registration in accounting of related operations to the granting and justification of the advance is presented like in Figure no. 3 and Figure no. 4.

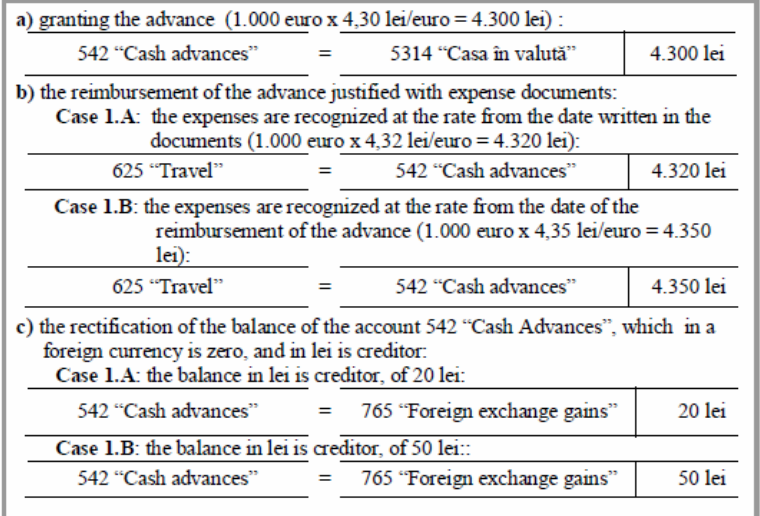

Figure no.3. Accounting of Cash Advance, with Assessment at the Exchange Rate of the Day - Case 1

\begin{tabular}{|c|c|c|c|}
\hline \multicolumn{4}{|c|}{ a) granting the advance ( 1.000 euro $\times 4,35$ lei/euro $=4.350$ lei): } \\
\hline 542 "Cash advances" & $=$ & 5314 "Casa în valută" & 4.350 lei \\
\hline \multicolumn{4}{|c|}{ b) the reimbursement of the advance justified with expense documents: } \\
\hline \multicolumn{4}{|c|}{$\begin{array}{l}\text { Case 2.A: the expenses are recognized at the exchange rate written on the documents } \\
(1.000 \text { euro } \times 4,32 \text { lei/euro }=4.320 \text { lei): }\end{array}$} \\
\hline 625 "Travel" & $=$ & 542 "Cash advances" & 4.320 lei \\
\hline \multicolumn{4}{|c|}{$\begin{array}{l}\text { Case 2.B: the expenses are recognized at the exchange rate from the date of } \\
\text { the reimbursements of the advance }(1.000 \text { euro } x 4,30 \text { lei/euro }=4.300 \text { lei) }\end{array}$} \\
\hline 625 "Travel" & $=$ & 542 "Cash advances" & 4.300 lei \\
\hline \multicolumn{4}{|c|}{$\begin{array}{l}\text { c) the rectification of the balance of the account } 542 \text { "Cash advance", which in a foreign } \\
\text { currency is zero and in lei is debtor: } \\
\text { Case } 2 . A \text { : the balance in lei is debtor, of } 30 \text { lei: }\end{array}$} \\
\hline 665 "Foreign exchange losses" & $=$ & 542 "Cash advances" & 30 lei \\
\hline \multicolumn{3}{|c|}{ Cazul 2.B: the balance in lei is debtor, of 50 lei: } & \\
\hline 665 "Foreign exchange losses" & $=$ & 542 "Cash advances" & 50 lei \\
\hline
\end{tabular}

Figure no. 4. Accounting of Cash Advance, with Assessment at the Exchange Rate of the Day - Case 2 
We observe the fact that, up to the end, no matter the exchange rate used at the crediting of the account 542 "Cash Advance", the differences of exchange rate of the cash advance, between the rate from the date when the advance was granted (used at the debiting of the account) and the rate from the date of the liquidation of the advance (used at the crediting of the account), will be reflected in the accounting.

We have to state the fact that, in the situation in which the justification of the cash advance in a foreign currency is not done until the end of the month when it was granted, the entity will proceed to assess it at the end of the month at the exchange rate of the foreign exchange market, notified by the National Bank of Romania from that particular last banking day of the month and will recognize in the accounting the exchange gains and losses. Therefore, the differences of exchange rate between the date of the liquidation of the advance and the date of the granting of the advance could be completely recognized in the accounting at the justification of the advance or could be presented during a two months period.

The influence of the exchange rate used in recognizing the travel expenses (the rate from the date of the documents, that is, the rate from the settlement of advance) on the information presented in the Profit and Loss Account, for one of the cases of our examples, that is Case 1, is synthetically presented in Figure no.5. We complete the data of the example, considering that in the case in which an entity, which before the recognition of the travel expenses, presented the following situation of the results: operating profit 50.000 lei; profit from the financial activity 2.000 lei.

\begin{tabular}{|c|c|c|c|c|}
\hline Indicators & $\begin{array}{l}\text { The situation } \\
\text { before } \\
\text { recognizing } \\
\text { the travel } \\
\text { expenses } \\
\text { aboard }\end{array}$ & $\begin{array}{l}\text { Case 1.A: } \\
\text { Exchange rate } \\
\text { at the date of } \\
\text { the documents } \\
\text { (4,32 lei/euro) }\end{array}$ & $\begin{array}{l}\text { Case 1.B: } \\
\text { Exchange rate at } \\
\text { the date of the } \\
\text { reimbursement } \\
\text { of the advance } \\
(4,35 \text { lei/euro) }\end{array}$ & $\begin{array}{l}\text { Difference: } \\
\text { (col. } 3- \\
\text { col. 2) }\end{array}$ \\
\hline $\begin{array}{l}\text { Profit from the operation before } \\
\text { the recognition of the travel } \\
\text { expenses abroad }\end{array}$ & 50.000 lei & 50.000 lei & 50.000 lei & 0 lei \\
\hline Travel expenses & - & 4.320 lei & 4.350 lei & +30 lei \\
\hline Operating profit & 50.000 lei & 45.680 lei & 45.650 lei & -30 lei \\
\hline $\begin{array}{l}\text { Profit from the financial } \\
\text { activity before the recognition } \\
\text { of the travel expenses abroad }\end{array}$ & 2.000 lei & 2.000 lei & 2.000 lei & 0 lei \\
\hline Exchange gains & - & 20 lei & 50 lei & +30 lei \\
\hline $\begin{array}{l}\text { Profit from the financial } \\
\text { activity }\end{array}$ & 2.000 lei & 2.020 lei & 2.050 lei & +30 lei \\
\hline Gross profit & 52.000 lei & 47.700 lei & 47.700 lei & 0 lei \\
\hline
\end{tabular}

\section{Figure no. 5 The Influence of the Exchange Rate Used to Recognize the Expenses, on the Information Presented in the Profit and Loss Account - Case 1}

It is noted that using a higher exchange rate leads to an increase in operating expenses, that is at a decrease of the operating profit, at the same time with the increase of the financial income, respectively, the increase of profit from financial activities with the same value, in our example, 30 lei.

In the above examples we considered that the cash advance granted was sufficient to cover the travel expenses abroad. In practice, however, there are situations where the sum of the amounts paid in currency during the travel abroad is higher than the amount of the cash advance granted, or the travel abroad was made without the person that travels having received a cash advance on departure. In such cases, the entity should recognize a debt in the case of that person for the currency payments made by it. We believe that, for consistency, and in such cases we should apply the same treatment, meaning that the recognition of the expenses can be carried out either at the rate on the day of operation, or at the rate of the submission date of the statement of expenditure. 
In addition, we must point out the fact that depending on the nature of expenses to be recognized as a result of payments made in foreign currency the cash advances may encounter some matters of taxation, in that the tax outcome or the profit tax could be affected, and therefore the net result of the financial the year. Such tax problems can occur in the case of the limited deductibility of expenses, such as for example the entertainment expenses. Where payments in foreign currency (cash in advance) are made for entertainment expenses, if the evaluation is done at a higher or lower rate it affects the deductible or nondeductible amount when calculating the taxable income.

\section{The Definition of Cash Advances and the Related Account}

Cash advances are defined in the specialized literature as the amounts assigned by the entity to the staff, administrators or other persons authorized to make payments on its account. Substantially the same definition results from the Accounting Regulations content, which in point 176, Paragraph (1), provide that: "Cash, available to staff or third parties, in order to make payments on the account of the entity is recorded separate in the accounting books (Account 542 "Cash Advances")". From the text above, as well as from the operating rule formulated in the Accounting Regulations for account 542 "Cash advances" it results that cash advances may be paid only in cash. However, in a footnote attached to the account 542"Cash advances" in the Chart of accounts provided in the Accounting regulations prescribed in point 329 , it is stated that "in this account shall be recorded also the amounts paid by the card system." Therefore such amounts may be made available to the staff or thirds not only in cash but also through the card system.

Therefore, we find it necessary to temporarily integrate the text of point 176, Paragraph (1) and the operating rules for account 542 "Cash advances" in order to show that: this account also allows the accounting of "amounts granted by the card system."

Also, from the operating rule of the account 542 "Cash advances" results that are recorded in this account, among others, in debit the "favorable foreign exchange differences related to foreign currency cash advances recorded at the end of the month and of the year (765)", and in credit the "unfavorable foreign exchange differences related to foreign currency cash advances, registered at the end of the month and of the year or the liquidation thereof (665)." We find that the rule formulated for the debit omitted the exchange differences recorded at the "liquidation of advances". Therefore, it must be completed the rule regarding the operation of the account, in order to suggest that this account is debited also with the favorable foreign exchange differences registered at the liquidation of the advances made in foreign currency. Thus, the rule relating to favorable foreign exchange differences would be: in the debit of account 542 "Cash Advances" there are "favorable exchange differences relating to foreign currency cash advances recorded at the end of the month and at the closing of the financial year, or their liquidation thereof (765).“

\section{About the Presentation of the Cash Advances in the Financial Statements}

Regarding the presentation in the financial statements (specifically in the balance sheet) of the cash advances, from the Accounting Regulations text it results that their balance is not present in the cash but in the debt category, for which they will be transferred from the Cash Account 542 to account 4282 or 461, according to case. Specifically, in point 175, Paragraph (3) it is provided that: "The amounts of cash advances granted by law and not reimbursed until the date of the balance sheet, evidenced in the sundry debtors account (461 "Sundry debtors") or debts related to personnel (4282 "Other claims regarding the personnel"), depending on the nature of the debt". We believe, too, that such values are debt type elements rather than elements of cash debt as long as they were advanced to persons who will justify their use or return them. Therefore, the transfer of such values from a cash 
account to a receivables account is justified and, as a result, they will be shown in the balance sheet structure under heading B.II. DEBTS.

Of course, after such operations the account 542 "Cash advances" would not have a balance and, therefore, would no longer be present in the balance sheet. However, in the content of the same Accounting regulations, when the balance sheet structure is presented (point 330, for the extended balance sheet, or point 331, for the abbreviated balance sheet), between the accounts that form the content of the position B. IV. CASH AND BANK ACCOUNTS (i.e., line 34), the account 542 is included. A statement in this regard from the structure of the extended balance sheet is as follows:

\begin{tabular}{|l|l|l|l|}
\hline $\begin{array}{l}\text { IV. CASH AND BANK ACCOUN TS } \\
\text { (account } 5112+512+531+532+541+542)\end{array}$ & 34 & & \\
\hline
\end{tabular}

\section{Figure no. 6 Excerpt from the Balance Sheet Structure}

Therefore, is imposed a correction of the content of the position B. IV. CASH AND BANK ACCOUNTS from the Balance sheet structure shown in the Accounting regulations, in order to eliminate the 542 account from the accounts listed between brackets.

Conclusions: We believe that it is important for the entity to clearly state, under the accounting policies manual, the option for one of the two possibilities referring to the rate used in the assessment in order to recognize the expenses incurred in the case of the foreign currency payments from cash advances. This is especially important as such expenses paid from foreign currency cash advances have significant weights and they have values high enough so as to generate significant information. Thus the conditioner of the financial statements or the managers could not use the exchange rate to "arrange" information at will, following the increase or decrease in the operating income, respectively, the decrease or increase of the net financial activity. Also, the accounting normalization body should intervene on the accounting regulations applicable to the economic operators in order to improve them, integrating them or removing contradictory elements.

\section{References}

1. CECCAR (2010), Ghid practic de aplicare a Reglementărilor contabile conforme cu directivele europene aprobate prin OMFP nr. 3055/2009, Ed. CECCAR, Bucureşti

2. Dumitrean, E. (2008), Contabilitate financiară, Ed. Sedcom Libris, Iaşi

3. Moroşan, I. (2010), Contabilitate financiară şi de gestiune: studii de caz şi sinteze de reglementări, Ed. CECCAR, Bucureşti

4. Pătruț, V., Rotilă, A. (2010), Contabilitate şi diagnostic financiar-fundamente teoretice şi aplicaţii practice, Ediţia a II-a revizuită şi actualizată, Ed. Sedcom Libris, Iaşi

5. Pântea, I., P., Bodea, Gh. (2008), Contabilitatea financiară românească conformă cu directivele europene, Ediţia a III-a, Ed. Intelcredo, Deva

6. Ristea, M., Dumitru, C.,G., Ioanăş, C., Irimescu, A. (2009), Contabilitatea societăţilor comerciale, vol. 1 şi vol. 2, Ed. Universitară, Bucureşti

7. The Accounting Law no. 82/1991, republished in the Official Journal of Romania no. 454/ 2008, with subsequent amendments

8. Law no. 571/2003, regarding the Tax Code, with subsequent amendments

9. The Order of the Public Finances Minister no. 3055/2009 for the approval of accounting regulations in compliance with European directives, published in the Official Journal of Romania no. 766/2009 and 766 bis/2009, with subsequent amendments

10. The Order of the Public Finances Minister no. 2861/2009 for the approval of Norms for organizing and performing the inventory of elements such as assets, debts and equity, published in the Official Journal of Romania no. 704/2009 